\title{
Effects of crude protein and lysine contents of the diet on growth and body composition of slow-growing commercial broilers from 42 to 77 days of age
}

\author{
Maxime QUENTIN ${ }^{\mathrm{a}, \mathrm{b}}$, Isabelle BOUVAREL ${ }^{\mathrm{b}}$, Michel PICARD $^{\mathrm{a} *}$ \\ a Institut National de la Recherche Agronomique-Station de Recherches Avicoles, \\ 37380 Nouzilly, France \\ ${ }^{\mathrm{b}}$ Institut Technique de 1'Aviculture, 28 rue du rocher, 75008 Paris, France
}

(Received 1 July 2004; accepted 11 March 2005)

\begin{abstract}
The effects of two dietary crude protein levels $(\mathrm{H}=22.5$ and $\mathrm{L}=17 \%$ on average $)$ and four lysine levels $(0.56,0.66,0.76$ and $0.86 \%)$ were compared in a $2 \times 4$ factorial design, on growth and carcass composition of slow growing broilers (Label) during the finishing period (42-77 days). There were six pens of 28 male chickens per treatment. In each pen, 14 chicks received a stimulating starter diet (13 MJ.kg ${ }^{-1}, 1.4 \%$ lysine) and the other 14 chicks a poor starter diet $\left(12.1 \mathrm{MJ} \cdot \mathrm{kg}^{-1}, 1.1 \%\right.$ lysine) from 0 to 6 days of age. The starter regime had no significant effect on subsequent performances and no interaction with the other traits. During the finishing period, lysine deficiency at $0.56 \%$ induced feather pecking and cannibalism resulting in more severe mortality with the $\mathrm{H}(33.9 \%)$ than the L diet (5.4\%). Growth, feed conversion and breast meat yield were significantly improved by lysine supplementation up to $0.76 \%$ in the diet whatever the protein level. However, the deterioration of growth and feed conversion for lower lysine levels was more severe for the $\mathrm{H}$ diet compared to the $\mathrm{L}$ diet (interaction $P<0.001)$. The $\mathrm{H}$ fed chickens had less abdominal fat $(3.3 \%)$ than the $\mathrm{L}$ fed chickens $(4.3 \%)$ without a significant effect of the lysine level. The lysine requirement measured by regression (exponential and ascending line with a plateau) was close to $0.68 \%$. High dietary protein levels associated with subdeficiency in lysine might favour cannibalism in label chickens during the finishing stage.
\end{abstract}

meat chicken / growth / protein / lysine / body composition / cannibalism

Résumé - Effet de la teneur du régime en protéine et lysine sur la croissance et la composition corporelle de poulets de chair à croissance lente entre $\mathbf{4 2}$ et 77 jours d'âge. Les effets de huit aliments différant par leurs taux protéiques ( $\mathrm{H}=22,5$ et $\mathrm{L}=17 \% \mathrm{~PB}$ en moyenne) et leurs taux de lysine $(0,56,0,66,0,76$ et $0,86 \%)$ selon un schéma factoriel $(2 \times 4)$, ont été comparés sur la croissance et la composition corporelle de poulets de chair à croissance lente (Label) pendant la période de finition (42-77 jours). Il y avait 6 parquets de 28 poulets males par traitement. Dans chaque parquet, 14 poussins avaient reçu de 0 à 6 jours, un régime de démarrage concentré ( $13 \mathrm{MJ} \cdot \mathrm{kg}^{-1} ; 1,4 \%$ lysine) et les 14 autres un régime plus pauvre $\left(12,1 \mathrm{MJ} \cdot \mathrm{kg}^{-1} ; 1,1 \%\right.$ lysine $)$. Le régime de démarrage n'a eu aucun effet sur les performances ultérieures ni d'interaction significative avec les autres traitements.

* Corresponding author: picard@tours.inra.fr 
Pendant la période de finition, le taux le plus bas de lysine $(0,56 \%)$ a induit du picage et du cannibalisme conduisant à une mortalité plus sévère pour le régime $\mathrm{H}(33,9 \%)$ que pour le régime $\mathrm{L}(5,4 \%)$. La croissance, l'indice de consommation et le rendement en filets étaient significativement améliorés par la supplémentation en lysine jusqu' au niveau de $0,76 \%$ quel que soit le taux protéique. Cependant, la détérioration de la croissance et de l'indice de consommation pour des teneurs de lysine inférieures, était plus marquée pour le régime $\mathrm{H}$ que pour le régime $\mathrm{L}$ (Interaction $P<0,001$ ). Les poulets consommant les régimes $\mathrm{H}$ avaient en moyenne moins de gras abdominal $(3,3 \%)$ que ceux consommant les aliments L $(4,3 \%)$ sans effet ou interaction avec le taux de lysine. Le besoin en lysine mesuré par régression (exponentielle et linéaire à plateau) était proche de $0,68 \%$. Un taux protéique élevé associé avec une subcarence en lysine peut favoriser le cannibalisme chez les poulets label en finition.

poulet de chair / croissance / protéine / lysine / composition corporelle / cannibalisme

\section{INTRODUCTION}

The development of new types of broiler meat production in France requires updates of the nutritional requirements of these chickens. In 2003, half of the chicken meat consumed came from genotypes with relatively slow growth and a third of the consumption from label chickens, whose life span is at least twice longer compared to a regular broiler for the same final body weight. A comparison of the dietary regimes offered to the different genotypes has been published [16]. Several differences between fast and slow growing chickens suggest a more precise decomposition of the nutritional factors that might be involved.

Do slower growing birds require less protein and amino acids than fast growing broilers? The answer to this question varies from one author to another. Even though most publications report significant genotype $\times$ diet interactions on growth $[12,21$, $22]$ and body composition [1, 4], some note that if expressed in dietary concentration the requirement in lysine for example, does not vary between slow and fast growing chickens [7]. The efficiency of protein deposition in the body might remain relatively constant even when a layer type bird is compared to a broiler [15].

Recent research results suggest that the starter diet might have long-term effects on broiler growth and body composition $[5,9$, 10] but these effects might be due to the increased rate of growth in the young mod- ern broiler from hatching on and might be less prevalent for slower growing birds.

The present research studied the responses of slow growing male chickens to diets differing in crude protein and essential amino acid contents at two critical periods of their life from biological (the first week) and economical (the finishing period: 42 to 77 days) points of view. Finally, increasing lysine levels in the diet were compared at two different crude protein dietary concentrations.

\section{MATERIALS AND METHODS}

\subsection{Experimental design and housing}

One thousand three-hundred and fortyfour one day-old commercial male chicks of a label genotype were obtained from a commercial hatchery. Upon arrival, the chicks were weighed and separated into groups of 50 individuals and randomly distributed into 12 wood shaving floor pens ( 112 chicks per pen) in an environmentally-controlled poultry shed. From 1 to 6 days of age, 6 pens (odd numbers) received starter diet $\mathrm{S}$ - and the other 6 pens (pair numbers) starter diet $\mathrm{S}+$ ad libitum. All chicks were vaccinated against coccidiosis (Paracox8, Scheringplough (C) at 5 days of age. At 6 days of age the chicks were weighed, wing banded and randomly redistributed into 48 floor pens of $3 \mathrm{~m}^{2}$. However, in each pen there were 14 chicks having eaten the starter feed S-and 14 chicks having eaten the starter feed $\mathrm{S}+$. 
Temperature was $32{ }^{\circ} \mathrm{C}$ from Day 0 to Day 7 and progressively reduced to reach $21^{\circ} \mathrm{C}$ after Day 28 . Lighting was $24 \mathrm{~h}$ a day during the first 3 days and then reduced to $14 \mathrm{~h}$ until Day 14. An increase of $2 \mathrm{~h}$ light a week was applied after Day 21 to reach $16 \mathrm{~h}$ per day from Day 21 until the end of the experiment. Light intensity was 50 lux for the first 3 days, 20 lux until Day 15 and then reduced to reach 10 lux at Day 21 and 5 lux after 42 days of age.

From 7 to 42 days of age, the chickens received the same grower feed and the final stage of the experiment lasted from 42 to 77 days of age. During that period there were 8 different experimental feeds distributed each to 6 different pens of birds. The 8 treatments were arranged as a factorial design: 2 crude protein levels $\times 4$ lysine contents. Each group of 8 neighbouring pens was considered as a block and in each block, the 8 experimental feeds were tested.

\subsection{Diets}

Feeds were prepared by the INRA Poultry Research Station (Nouzilly, France) a week before their use and analysed for dry matter, nitrogen and total amino acid contents using ion-exchange chromatography by Ajinomoto (Amiens, France). For clarity, the analysed values are used in the rest of the text. The starter feeds (first week of age) were presented as crumbs and the other feeds were steam pelleted (diameter $2.5 \mathrm{~mm}$ ). The two starter diets were designed to be as different as possible while remaining close to the limits of practical uses (Tab. I). The S+ diet contained $13 \mathrm{MJ} \cdot \mathrm{kg}^{-1}$ (calculated), 22.1 crude protein (CP) and $1.34 \%$ lysine, although the $\mathrm{S}$ - feed diet was less concentrated, $12.1 \mathrm{MJ} \cdot \mathrm{kg}^{-1}, 20.6 \% \mathrm{CP}$ and $1.03 \%$ lysine. When tested on fast growing broilers, the S- diet compared to S+ induced a $14 \%$ retardation at 6 days of age with long lasting effects on growth and body composition [17]. The grower feed was intermediate between the two starters (Tab. I). The two finisher basal diets (42-77 days of age) combined cereals with sources of protein from corn gluten meal, peas, a limited amount of soybean and synthetic amino acids, in order to differ in CP levels by $5.5 \%$ with a similar low level of total lysine $(0.56 \%)$. Graded supplementation in lysine $\mathrm{HCl}$ led to a range of four lysine levels $(\mathrm{A}=0.56$; $\mathrm{B}=0.66 ; \mathrm{C}=0.76$ and $\mathrm{D}=0.86 \%$ ). Special care was observed to balance the other essential amino acids and also the electrolyte levels in these feeds (Tab. I).

\subsection{Measures}

Mortality was recorded daily for each pen. All chickens were individually weighed and food intake was measured per pen at $6,21,35,42,49,56,70$ and 77 days of age. Before slaughter at 77 days of age, 12 chickens per treatment (4 per pen, $2 \mathrm{~S}+$ and $2 \mathrm{~S}-$ ) were identified to match the 70 days average (and standard deviation) bodyweight of each treatment (2 Starter diets $\times 2$ Protein levels $\times 4$ Lysine levels). On day 77, all chickens were fasted 8 hours before slaughter and the 192 selected chickens were transported to the slaughterhouse. After scalding, automatic plucking and manual gut removal, the carcasses were chilled in a cold room for $24 \mathrm{~h}$ at $2{ }^{\circ} \mathrm{C}$. The right and left Pectoralis major and minor, and abdominal fat were dissected and weighed [13]. Carcass composition data were expressed as \% of live body weight.

\subsection{Statistical analysis}

Mortality (\% per pen) data were subjected to Arc sin square root transformation prior to analysis. The effect of the starter diet during the first week was analysed by a one way ANOVA of the two treatments with 6 replicates (112 chicks per pen). The starter diet effect and its interactions with $\mathrm{CP}$ and lysine levels during the finishing period, on body weight, mortality and body composition were analysed by a three way ANOVA by considering each pen as two sub-pens composed by the average performances of the $\mathrm{S}+$ and the $\mathrm{S}$ - chickens per pen. The effects of CP and lysine levels on 
Table I. Composition and nutrient content of the 3 experimental diets

\begin{tabular}{|c|c|c|c|c|c|c|c|c|c|c|c|}
\hline \multirow[b]{3}{*}{ Ingredient } & \multirow{3}{*}{$\frac{\text { Starter }}{\mathrm{S}-}$} & \multirow{3}{*}{$\frac{0-6 \mathrm{~d}}{\mathrm{~S}+}$} & \multirow{3}{*}{$\begin{array}{l}\text { Grower } \\
7-42 d\end{array}$} & \multicolumn{8}{|c|}{ Finisher 42-77 d } \\
\hline & & & & \multicolumn{4}{|c|}{ Low Crude Protein } & \multicolumn{4}{|c|}{ High Crude Protein } \\
\hline & & & & A & B & $\mathrm{C}$ & $\mathrm{D}$ & A & B & $\mathrm{C}$ & $\mathrm{D}$ \\
\hline Corn & 31.47 & 29.95 & 43.82 & 64.59 & 64.59 & 64.59 & 64.59 & 17.98 & 17.98 & 17.98 & 17.98 \\
\hline Wheat & 29.00 & - & 11.81 & - & - & - & - & 40.00 & 40.00 & 40.00 & 40.00 \\
\hline Soybean meal $48 \%$ & 31.80 & 14.00 & 34.50 & 2.00 & 2.00 & 2.00 & 2.00 & 1.80 & 1.80 & 1.80 & 1.80 \\
\hline Saccharose & - & 19.50 & - & - & - & - & - & - & - & - & - \\
\hline Corn starch & - & - & - & 0.38 & 0.26 & 0.13 & - & 0.38 & 0.26 & 0.13 & - \\
\hline Soybean toasted & - & 20.00 & - & 6.00 & 6.00 & 6.00 & 6.00 & - & - & - & - \\
\hline Corn gluten meal & - & 10.00 & - & 10.00 & 10.00 & 10.00 & 10.00 & 23.00 & 23.00 & 23.00 & 23.00 \\
\hline Peas & - & - & - & 9.00 & 9.00 & 9.00 & 9.00 & 8.00 & 8.00 & 8.00 & 8.00 \\
\hline Colza oil & 2.50 & - & 4.30 & 1.45 & 1.45 & 1.45 & 1.45 & 2.54 & 2.54 & 2.54 & 2.54 \\
\hline Calcium carbonate & 1.02 & 0.92 & 0.98 & 1.28 & 1.28 & 1.28 & 1.28 & 1.45 & 1.45 & 1.45 & 1.45 \\
\hline Dicalcium phosphorus & 2.00 & 2.22 & 2.07 & 1.90 & 1.90 & 1.90 & 1.90 & 1.65 & 1.65 & 1.65 & 1.65 \\
\hline Sodium hydrogenocarbonate & - & 0.40 & - & 0.80 & 0.80 & 0.80 & 0.80 & 0.90 & 0.90 & 0.90 & 0.90 \\
\hline L-Lysine $\mathrm{HCl}$ & - & 0.49 & - & - & 0.12 & 0.25 & 0.38 & - & 0.12 & 0.25 & 0.38 \\
\hline DL-Methionine & 0.22 & 0.30 & 0.22 & 0.12 & 0.12 & 0.12 & 0.12 & - & - & - & - \\
\hline L-Threonine & 0.04 & 0.10 & - & 0.04 & 0.04 & 0.04 & 0.04 & - & - & - & - \\
\hline L-Tryptophan & - & 0.05 & - & 0.04 & 0.04 & 0.04 & 0.04 & - & - & - & - \\
\hline L-Arginine & - & - & - & 0.10 & 0.10 & 0.10 & 0.10 & - & - & - & - \\
\hline Salt & 0.45 & 0.47 & 0.30 & 0.30 & 0.30 & 0.30 & 0.30 & 0.30 & 0.30 & 0.30 & 0.30 \\
\hline Premix A & 0.50 & 0.50 & 0.50 & 0.50 & 0.50 & 0.50 & 0.50 & 0.50 & 0.50 & 0.50 & 0.50 \\
\hline Avizyme $1500^{\mathrm{B}}$ & - & 0.10 & - & - & - & - & - & - & - & - & - \\
\hline \multirow[t]{2}{*}{ Sodium Bentonite } & 1.00 & 1.00 & 1.50 & 1.50 & 1.50 & 1.50 & 1.50 & 1.50 & 1.50 & 1.50 & 1.50 \\
\hline & \multicolumn{11}{|c|}{ Total is $100 \%$} \\
\hline \multicolumn{12}{|l|}{ Composition } \\
\hline $\operatorname{AME}\left(\mathrm{MJ} \cdot \mathrm{kg}^{-1}\right)$ & 12.12 & 13.00 & 12.54 & 13.04 & 13.04 & 13.04 & 13.04 & 13.04 & 13.04 & 13.04 & 13.04 \\
\hline Crude protein (\%) & 20.90 & 22.90 & 21.20 & 17.05 & 17.16 & 17.28 & 17.40 & 22.60 & 22.72 & 22.84 & 22.96 \\
\hline Crude protein $(\%)^{*}$ & 20.63 & 22.12 & 21.06 & 16.44 & 16.50 & 16.50 & 17.30 & 22.69 & 22.75 & 22.38 & 23.00 \\
\hline \multicolumn{12}{|l|}{ Total Amino Acids : } \\
\hline Lysine $(\%)$ & 1.10 & 1.40 & 1.15 & 0.60 & 0.70 & 0.80 & 0.90 & 0.60 & 0.70 & 0.80 & 0.90 \\
\hline Lysine (\%)* & 1.03 & 1.34 & 1.08 & 0.56 & 0.66 & 0.76 & 0.85 & 0.56 & 0.64 & 0.78 & 0.86 \\
\hline Methionine + cystine $(\%)$ & 0.91 & 1.03 & 0.91 & 0.75 & 0.75 & 0.75 & 0.75 & 0.89 & 0.89 & 0.89 & 0.89 \\
\hline Methionine + cystine $(\%)^{*}$ & 0.80 & 0.92 & 0.83 & 0.65 & 0.64 & 0.65 & 0.65 & 0.78 & 0.81 & 0.79 & 0.80 \\
\hline Threonine & 0.81 & 0.91 & 0.80 & 0.64 & 0.64 & 0.64 & 0.64 & 0.76 & 0.76 & 0.76 & 0.76 \\
\hline Tryptophane & 0.25 & 0.27 & 0.26 & 0.16 & 0.16 & 0.16 & 0.16 & 0.16 & 0.16 & 0.16 & 0.16 \\
\hline \multicolumn{12}{|l|}{ Digestible Amino Acids**: } \\
\hline Lysine Dig (\%) & 0.91 & 1.23 & 0.98 & 0.48 & 0.58 & 0.68 & 0.78 & 0.48 & 0.56 & 0.69 & 0.77 \\
\hline Methionine + cystine Dig $(\%)$ & 0.72 & 0.84 & 0.75 & 0.65 & 0.65 & 0.65 & 0.65 & 0.80 & 0.80 & 0.80 & 0.80 \\
\hline Threonine Dig (\%) & 0.70 & 0.79 & 0.69 & 0.55 & 0.55 & 0.55 & 0.55 & 0.64 & 0.64 & 0.64 & 0.64 \\
\hline Tryptophane Dig (\%) & 0.22 & 0.24 & 0.22 & 0.15 & 0.15 & 0.15 & 0.15 & 0.14 & 0.14 & 0.14 & 0.14 \\
\hline $\mathrm{Ca}(\%)$ & 1.12 & 1.12 & 1.12 & 1.12 & 1.12 & 1.12 & 1.12 & 1.12 & 1.12 & 1.12 & 1.12 \\
\hline AvailableP (\%) & 0.45 & 0.45 & 0.45 & 0.40 & 0.40 & 0.40 & 0.40 & 0.39 & 0.39 & 0.39 & 0.39 \\
\hline D.E.B. $\left(\mathrm{mEq} \cdot \mathrm{kg}^{-1}\right)^{\mathrm{C}}$ & 226 & 204 & 231 & 207 & 207 & 207 & 207 & 198 & 198 & 198 & 198 \\
\hline
\end{tabular}

* Measured values. **Digestible protein and amino acid were calculated with the Rhône Poulenc Animal Nutrition feedstuff digestible coefficient and corrected for the difference between measured and calculated values. A Premix composition (as mg per kg of diet): Ca, 1600; Co, 0.6; Cu, 25; Fe, 50; I, 1; Mn, 85; Se, 0.25; Zn, 60. Vitamin supplies: vitamin A (all-trans-retinol), $10000 \mathrm{IU}$; cholecalciferol, $2000 \mathrm{IU}$; vitamin E (DL-alpha-tocopheryl acetate), $30 \mathrm{mg}$; thiamine, $1.5 \mathrm{mg}$; riboflavin, $4 \mathrm{mg}$; calcium pantothenate, $10 \mathrm{mg}$; vitamin $\mathrm{B}_{12}, 0.015 \mathrm{mg}$; menadione, $2 \mathrm{mg}$; pyridoxine hydrochloride, $2.5 \mathrm{mg}$; folic acid, $0.4 \mathrm{mg}$; biotin, $0.2 \mathrm{mg}$; choline, $500 \mathrm{mg}$; niacin, $30 \mathrm{mg}$; butylated hydroxyl toluene, $125 \mathrm{mg} .{ }^{\mathrm{B}}$ Danisco Animal Nutrition, UK. ${ }^{\mathrm{C}}$ Dietary Electrolyte Balance $\left(\mathrm{Na}^{+}+\mathrm{K}^{+}-\mathrm{Cl}^{-}\right)$. 
Table II. Probability of the effects of the starter feed (S+ or S-), the crude protein and lysine level of the feed eaten from 42 to 77 days of age (see Table I) and their interactions on body weight and body composition at 77 days of age. $\mathrm{N}=6$ half pens of 14 chickens for body weight and 2 chickens for body composition.

\begin{tabular}{|c|c|c|c|c|c|}
\hline \multirow[t]{2}{*}{ Source of variation } & \multicolumn{2}{|c|}{ Body Weight (g) } & \multirow{2}{*}{$\begin{array}{l}\text { Weight Gain } \\
\quad(\mathrm{g} \text { per d) }\end{array}$} & \multirow{2}{*}{$\begin{array}{c}\text { Breast Meat } \\
\text { Yield (\%) }\end{array}$} & \multirow{2}{*}{$\begin{array}{c}\text { Abdominal Fat } \\
(\%)\end{array}$} \\
\hline & $42 \mathrm{~d}$ & $77 \mathrm{~d}$ & & & \\
\hline Starter & NS & NS & NS & NS & NS \\
\hline CP Level & NS & $* * *$ & $* * *$ & NS & $* * *$ \\
\hline Lysine Level & NS & $* * *$ & $* * *$ & $* * *$ & NS \\
\hline Starter $\times \mathrm{CP}$ & NS & NS & NS & NS & NS \\
\hline Starter $\times$ Lysine & NS & NS & NS & NS & NS \\
\hline $\mathrm{CP} \times$ Lysine & NS & $* * *$ & $* * *$ & NS & NS \\
\hline Starter $\times \mathrm{CP} \times$ Lysine & NS & NS & NS & NS & NS \\
\hline
\end{tabular}

NS: $P>0.05 ; *: P<0.05 ; * *: P<0.01 ; * * *: P<0.001$

performances, feed intake and feed conversion ratio and body composition were analysed by a two way ANOVA.

When significant, the differences between the treatment means were tested using the Student-Newmann-Keuls multiple comparison test $(P<0.05)$.

Non linear regressions between body weight gain or feed conversion and lysine dietary level were performed on pen data, by fitting the data to an exponential model: i.e., Body Weight Gain $=\mathrm{A}-\mathrm{B} * \exp (-\mathrm{C} *$ Lysine level) with $\mathrm{A}=$ plateau; $\mathrm{B}$ and $\mathrm{C}=$ coefficient of the exponential curve; Lysine level $=$ level of lysine in the diet in \% [11] and by an ascending line with a plateau model [8].

\section{RESULTS}

\subsection{Effects of the starter diet}

The two-tested starter did not induce any measurable effect on chicken growth, mortality, or body composition in any of the controls. Their average ( \pm SE) body weight at 6 days of age was $104.3 \pm 0.4$ and $104.4 \pm$ $0.4 \mathrm{~g}$ per chick for $\mathrm{S}+$ and $\mathrm{S}-$ respectively. Similarly at 21 days of age their body weight showed no detectable treatment effect $(\mathrm{S}+=421.2 \pm 1.5$ and $\mathrm{S}-=422.6 \pm$ $1.5 \mathrm{~g}$ per chicken). Since no interaction with the other treatments reached significance (Tab. II), the protein nutrition factors during the finishing period were analysed independently from the starter diet.

\subsection{Feather pecking, mortality and growth performances}

Starting at 48 days of age (6 days after feeding the experimental diets), feather pecking was observed in some pens. The problem developed up to the end of the experimental period. Mortality was most pronounced in the group fed the lowest levels of lysine $(\mathrm{A}=0.56 \%)$ and with the basal diet rich in protein (Tab. III).

From 42 to 77 days of age, the interaction between $\mathrm{CP}$ and lysine was highly significant for feed intake and growth. The interaction was mainly attributable to the strong effect of lysine deficiency measured with the protein basal-diet. Parallel to its effect on mortality and feather pecking, low lysine levels (A and B) depressed growth rate and increased feed to gain ratio (Feed conversion). Higher levels of lysine (C and D) or 
Table III. Average mortality, body weight, feed intake, feed conversion, and body composition parameters of label chickens from 42 to 77 days of age, according to the crude protein and lysine level in the diet (see Tab. I). $\mathrm{N}=6$ pens of 28 male chickens per dietary treatment.

\begin{tabular}{|c|c|c|c|c|c|c|c|c|c|c|}
\hline \multirow{2}{*}{ CP Level } & \multirow{2}{*}{$\begin{array}{l}\text { Lysine } \\
\text { Level }\end{array}$} & \multirow{2}{*}{$\begin{array}{c}\text { Mortality } \\
(\%)\end{array}$} & \multicolumn{3}{|c|}{ Body Weight (g) } & \multirow{2}{*}{$\begin{array}{c}\text { Feed } \\
\text { intake } \\
42-77 \mathrm{~d} \\
\text { (g per d) }\end{array}$} & \multirow{2}{*}{$\begin{array}{l}\text { Weight } \\
\text { Gain } \\
42-77 \mathrm{~d} \\
\text { (g per d) }\end{array}$} & \multirow{2}{*}{$\begin{array}{l}\text { FCR } \\
42-77 \mathrm{~d} \mathrm{l} \\
(\mathrm{g} \text { per g) }(\end{array}$} & \multirow{2}{*}{$\begin{array}{l}\text { Breast } \\
\text { meat yield } \\
\% \text { of } \mathrm{BW})\end{array}$} & \multirow[t]{2}{*}{$\begin{array}{l}\text { Abdominal } \\
\text { fat }(\% \text { BW })\end{array}$} \\
\hline & & & $6 \mathrm{~d}$ & $42 \mathrm{~d}$ & $77 \mathrm{~d}$ & & & & & \\
\hline \multirow[t]{4}{*}{ High CP } & A & 33.9 & 104.4 & 1.232 & $2.046 \mathrm{e}$ & $84.4 \mathrm{c}$ & $23.6 \mathrm{e}$ & $3.57 \mathrm{a}$ & 12.13 & 2.20 \\
\hline & B & 7.1 & 105.3 & 1.239 & $2.520 \mathrm{c}$ & $107.9 \mathrm{~b}$ & $37.1 \mathrm{c}$ & $2.91 \mathrm{c}$ & 12.21 & 3.53 \\
\hline & $\mathrm{C}$ & 3.6 & 104.2 & 1.236 & $2.753 \mathrm{ab}$ & $117.8 \mathrm{a}$ & $44.0 \mathrm{ab}$ & $2.68 \mathrm{e}$ & 13.22 & 3.57 \\
\hline & $\mathrm{D}$ & 1.2 & 103.2 & 1.219 & $2.725 \mathrm{ab}$ & $116.6 \mathrm{a}$ & $43.6 \mathrm{ab}$ & $2.67 \mathrm{e}$ & 13.46 & 3.85 \\
\hline \multirow[t]{4}{*}{ Low CP } & A & 5.4 & 105.5 & 1.228 & $2.455 \mathrm{~d}$ & $110.3 \mathrm{~b}$ & $35.6 \mathrm{~d}$ & $3.10 \mathrm{~b}$ & 11.92 & 4.24 \\
\hline & B & 0.6 & 102.8 & 1.228 & $2.693 \mathrm{~b}$ & $119.2 \mathrm{a}$ & $42.5 \mathrm{~b}$ & $2.81 \mathrm{~d}$ & 12.71 & 4.31 \\
\hline & $\mathrm{C}$ & 1.2 & 104.3 & 1.245 & $2.798 \mathrm{a}$ & $122.1 \mathrm{a}$ & $45.0 \mathrm{a}$ & $2.71 \mathrm{e}$ & 12.80 & 4.56 \\
\hline & $\mathrm{D}$ & 1.8 & 104.9 & 1.219 & $2.758 \mathrm{a}$ & $118.3 \mathrm{a}$ & $44.6 \mathrm{a}$ & $2.65 \mathrm{e}$ & 13.25 & 3.99 \\
\hline SEM & & 2.0 & 0.31 & 3.25 & 35.1 & 1.74 & 1.01 & 0.04 & 0.10 & 0.10 \\
\hline
\end{tabular}

Probability

\begin{tabular}{lccccccccc} 
CP Level & $* * *$ & NS & NS & $* * *$ & $* * *$ & $* * *$ & $* * *$ & NS & $* * *$ \\
Lysine Level & $* * *$ & NS & NS & $* * *$ & $* * *$ & $* * *$ & $* * *$ & $* * *$ & NS \\
CP $\times$ Lysine & $*$ & NS & NS & $* * *$ & $* * *$ & $* * *$ & $* * *$ & NS & NS \\
\hline
\end{tabular}

a-e: different superscripts mean significant differences between the values; NS: $P>0.05 ; *: P<0.05$; **: $P<0.01 ; * * *: P<0.001$

of CP did not significantly affect growth, feed intake or feed conversion (Tab. III).

\subsection{Carcass composition}

No significant interaction was observed for breast meat yield or abdominal fat contents (Tab. III). The high dietary CP level did not significantly change the breast meat yield $(12.75 \%$ for high vs. $12.67 \%$ for low dietary CP Level) but a $23 \%$ reduction in fatness (estimated by the relative weight of abdominal adipose tissue) was measured. The lysine effect on breast meat yield was characterised by a steady improvement of breast meat yield from 0.56 to $0.86 \%$ of lysine in the diet although the two higher levels $(0.76$ and $0.86 \%)$ did not differ significantly (Fig. 1).

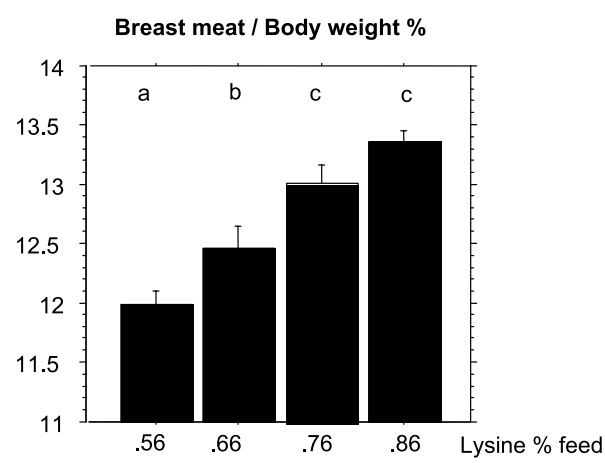

Figure 1. Effect of the dietary content of lysine from 42 to 77 days of age on breast meat yield (\% body weight) on label chickens at 77 days of age. Bars with different letters differ significantly (Newman and Keuls test; $P>0.05$ ). 


\section{DISCUSSION}

One of the major results of the present experiment is the interaction between dietary crude protein and lysine concentration. Not only the growth and feed conversion were strongly reduced by lysine deficiency when the dietary level of protein was high, but also the sensitivity of label type male chickens to feather pecking seemed involved. Although the dietary interaction was highly significant already at the first week of the experiment (at 49 days of age) on body weight gain when feather pecking was only starting, high mortality for treatments A and $\mathrm{B}$ with the high $\mathrm{CP}$ concentration might have accentuated the effect of the lysine deficiency on the final results.

Feather pecking and cannibalism are induced or aggravated by deficiencies in essential amino acids as by most nutritional imbalances in chickens [18]. However, there are limited recent publications on broilers since the fast growing birds have scarce problems of feather pecking in production. Conversely, the problem exists in label chickens and can be accentuated by outdoor weather conditions such as bright sunny days and stormy summers (field observation). In laying birds, a strong protein deficiency (involving concomitant essential amino acid imbalance) increases the occurrence of feather pecking and cannibalism [2] although the protein source (i.e., fishmeal compared to vegetable protein) does not seem to have a significant effect on this phenomenon [14]. The innovation of our result is to stress the interaction between high protein with low lysine levels as a critical factor for cannibalism in label chickens raised in confinement. Even though such a result was confirmed under more standard conditions of production, it might present some relevant nutritional application for this type of birds.

An interaction between $\mathrm{CP}$ and lysine has been reported in various genotypes [8, 20,23]. Sklan and Plavnik [20] showed that diets providing relative excesses of protein should be avoided since they decrease the efficiency of utilisation and increase essential AA requirements. It has been reported that the requirement in essential $\mathrm{AA}$ is increased when the CP level in the feed is high $[8,23]$. However, as suggested by the authors, other limiting factors might limit the lysine response in the lowest CP dietary levels. In the present study, all essential AA were provided above the chicken needs even in the low CP basal diet and the requirement for lysine was not increased parallel to the CP level of the diet. Fitting the regressions of the average weight gain (in $g$ per chicken per day) and of the feed conversion ratio with the lysine concentration in the feed, the estimation of the requirement for lysine was close to $0.68 \%$ of total lysine $(0.60 \%$ digestible) with the linear plateau model whatever the CP level for both variables (Tab. IV). Using $95 \%$ of the asymptote of an exponential regression, the feed conversion gave close results although the growth rate corresponded to a higher estimation of the lysine requirement for the high CP level ( $0.73 \%$ total lysine) than for the low CP level ( $0.67 \%$ total lysine). However, it seems that the negative effect of a sub deficiency in lysine on growth parameters is accentuated by a dietary excess of the other amino acids.

In accord with previous studies [1, 3, 15], we found that dietary $\mathrm{CP}$ level acts more on body deposition by decreasing fatness than by enhancing muscular growth. The metabolic explanation for this phenomenon remains to be elucidated [8]. In the absence of significant differences in feed intake when the birds were fed diets balanced in lysine (diet D), a possible explanation is a different energy partition. Birds fed a high $\mathrm{CP}$ diet should get rid of a higher amount of heat. This metabolic adaptation might be due to an excess of amino acids. A leaner carcass is poorer in energy than a fat one because protein deposition fixes more water than fat deposition. At similar body weight and feed intake, a leaner bird looses more heat.

Despite the relatively slow growth rate of the tested genotype, breast meat deposition 
Table IV. Calculation of the requirement in total lysine (and digestible lysine) of label chickens from 42 to 77 days of age according to the parameter (Weight gain of feed conversion ratio FCR), the protein level (see Tab. I), and the model of regression applied ( $\mathrm{N}=24$ pens per line).

\begin{tabular}{|c|c|c|c|c|c|c|}
\hline Model & Paramete & Cp Level & Equation & $\mathrm{R}^{2}$ & Requirement & $\begin{array}{c}\text { Confidence } \\
\text { Interval }(95 \%)\end{array}$ \\
\hline \multirow{4}{*}{$\begin{array}{l}\text { Ascending Line } \\
\text { With Plateau }\end{array}$} & \multirow{2}{*}{ Gain } & High & $43.8-169.3 *(0.679-[\mathrm{Lys}])$ & 0.97 & $\begin{array}{l}0.679 \\
(0.599)\end{array}$ & $\begin{array}{c}0.667 \text { To } 0.692 \\
\text { (0.587 To } 0.612 \text { ) }\end{array}$ \\
\hline & & Low & $44.8-68.9 *(0.694-[\mathrm{Lys}])$ & 0.97 & $\begin{array}{c}0.694 \\
(0.614)\end{array}$ & $\begin{array}{c}0.681 \text { To } 0.708 \\
\text { ( } 0.601 \text { To } 0.628)\end{array}$ \\
\hline & \multirow{2}{*}{ Fcr } & High & $2.68+8.34 *(0.668-[\mathrm{Lys}])$ & 0.95 & $\begin{array}{c}0.668 \\
(0.586)\end{array}$ & $\begin{array}{c}0.654 \text { To } 0.681 \\
(0.580 \text { To } 0.593)\end{array}$ \\
\hline & & Low & $2.68+2.95 *(0.702-[\mathrm{Lys}])$ & 0.93 & $\begin{array}{c}0.702 \\
(0.614)\end{array}$ & $\begin{array}{c}0.679 \text { To } 0.725 \\
\text { (0.596 To } 0.633)\end{array}$ \\
\hline \multirow{4}{*}{$\begin{array}{l}\text { Exponential } \\
\text { (95\% Asymp) }\end{array}$} & \multirow{2}{*}{ Gain } & High & $44.6+40147 * \exp \left(-13.5^{*}[\mathrm{Lys}]\right)$ & 0.97 & $\begin{array}{c}0.726 \\
(0.649)\end{array}$ & $\mathrm{Nc}$ \\
\hline & & Low & $45.1+18467 * \exp \left(-13.5^{*}[\mathrm{Lys}]\right)$ & 0.96 & $\begin{array}{c}0.667 \\
(0.586)\end{array}$ & $\mathrm{Nc}$ \\
\hline & \multirow{2}{*}{ For } & High & $2.66-9157 * \exp (-16.4 *[\mathrm{Lys}])$ & 0.95 & $\begin{array}{c}0.679 \\
(0.608)\end{array}$ & $\mathrm{Nc}$ \\
\hline & & Low & $2.64-195 * \exp (-10.9 *[\mathrm{Lys}])$ & 0.95 & $\begin{array}{l}0.670 \\
(0.597)\end{array}$ & $\mathrm{Nc}$ \\
\hline
\end{tabular}

responded highly significantly to lysine supplementation. Although the difference between diets $\mathrm{C}$ and $\mathrm{D}$ was not significant, the breast meat yield still did not reach a plateau at the level of $0.86 \%$ (Fig. 1). In fast growing broilers, the optimal breast meat yield is frequently observed for lysine levels lower or equal to that needed for optimal feed conversion [19]. Paradoxically, our results suggest that the estimation of the lysine requirement of slow growing finishing label chickens should take body composition into closer consideration.

At a younger age, a response to the starter feed richer in protein, amino acid and energy was not expressed by those slow growing birds although the same diets had highly significant and long lasting effects on protein growth in fast growing broilers [17]. The low protein requirement of slow growing chickens might be an explanation. However, expressed as a percentage of the diet, this kind of effect is not always found experimentally when comparing fast and slow growing chickens [i.e., 7]. Another possible explanation might be found in the imbalance induced by a too fast early muscular growth for the non-mature development of digestive organs and metabolism in fast growing broilers [5]. Conversely, the early development of the label type chicken is slower and more balanced with the early development of chicks that, at the beginning of their life, are not really different in size compared to their fast growing counterparts.

The balance between the degree of maturity and growth rate might be a useful direction of research to explain the variability of reaction of different genotypes to the same nutritional challenges [6]. A label or a broiler breeder have the same body weight at hatching and are sexually mature at the same age. Both age and live weight might jointly characterise a nutritional state. 


\section{CONCLUSION}

The requirement in lysine of male label type chickens raised in confinement from 42 to 77 days of age, was close to $0.68 \%$ ( $0.60 \%$ digestible lysine) in a $13 \mathrm{MJ} \cdot \mathrm{kg}^{-1}$ diet. It did not seem to vary with the crude protein content of the diet, but a more detailed evaluation of the effects of higher lysine levels on body composition (mainly breast meat yield) should be pursued.

A high level of crude protein in the diet accentuated the negative effects of a sub deficiency in lysine on growth and feed conversion and aggravated the consequences of feather pecking. A low $\mathrm{CP}$ diet with balanced levels of essential amino acids seems worthwhile for slow growing chickens in the finishing period. However, a low protein level even balanced in essential amino acids, induces fat deposition especially when slow growing label chickens are kept in confinement. The effects of exercise on a free-range area might change this conclusion.

The tested compositions of the starter diet did not affect performances of the slow growing chicks under our conditions. Further research taking into account both the maturity (age) and the growth (weight) of genotypes of different growth rate potentials might help to better characterise their nutritional state.

\section{ACKNOWLEDGMENTS}

The authors wish to thank Ajinomoto for the analyses of the experimental feeds, the technical staff of the experimental unit of the Poultry Research Station, particularly C. Bouchot and S. Nevoit for rearing the animals, and the staff of the genetics and meat quality teams for their help at the slaughterhouse and for carcass dissections.

\section{REFERENCES}

[1] Acar N., Moran E.T., Bilgili S.F., Live performance and carcass yield of male broilers from two commercial strain crosses receiving rations containing lysine below and above the established requirement between six and 8 weeks of age, Poultry Sci. 70 (1991) 23152321.

[2] Ambrosen T., Petersen V.E., The influence of protein level in the diet on cannibalism and quality of plumage of layers, Poultry Sci. 76 (1997) 559-563.

[3] Bartov I., Plavnik I., Moderate excess of dietary protein increases breast meat yield of broiler chicks, Poultry Sci. 77 (1998) 680-688.

[4] Bilgili S.F., Moran E.T., Acar N., Strain-cross response of heavy male broilers to dietary lysine in the finisher feed: live performance and further- processing yields, Poultry Sci. 71 (1992) 850-858.

[5] Eits R.M., Kwakkel R.P., Verstegen M.W.A., Emmans G.C., Responses of broiler chickens to dietary protein: effects of early life protein nutrition on later responses, Brit. Poultry Sci. 44 (2003) 1-12.

[6] Emmans G.C., Fisher C., Problems in nutritional theory, in: Fisher C., Boorman K.N. (Eds.), Nutrient requirement of poultry and nutritional research, Butterworth, London, UK, 1986, pp. 9-39.

[7] Han Y., Baker D.H., Lysine requirements of fast- and slow-growing broiler chicks, Poultry Sci. 70 (1991) 2108-2114.

[8] Hurwitz S., Sklan D., Talpaz H., Plavnik I., The effect of dietary protein level on the lysine and arginine requirements of growing chickens, Poultry Sci. 77 (1998) 689-696.

[9] Kerr B.J., Kidd M.T., Halpin K.M., McWard G.W., Quarles C.L., Lysine level increases live performances and breast meat yield in male broilers, J. Appl. Poultry Res. 8 (1999) 381-390.

[10] Kidd M.T., Fancher B.I., Lysine needs of starting chicks and subsequent effects during the growing period, J. Appl. Poultry Res. 10 (2001) 385-393.

[11] Leclercq B., Specific effect of lysine on broiler production: comparison with threonine and valine, Poultry Sci. 77 (1998) 118123 .

[12] Leclercq B., Beaumont C., Effects of genetic potential on the lysine requirement and economic results of simulated broiler flocks, Anim. Res. 50 (2001) 67-78.

[13] Marche G., La découpe anatomique et la dissection des volailles : le poulet, le canard, la dinde, SYSSAF-INRA, Nouzilly, France, 1985.

[14] McKeegan D.E.F., Savory C.J., MacLeod M.G., Mitchell M.A., Development of pecking damage in layer pullets in relation to 
dietary protein source, Brit. Poultry Sci. 42 (2001) 33-42.

[15] Morris T.R., Njuru D.M., Protein requirement of fast- and slow-growing chicks, Brit. Poultry Sci. 31 (1990) 803-809.

[16] Quentin M., Bouvarel I., Berri C., Le BihanDuval E., Baéza E., Jégo Y., Picard M., Growth, carcass composition and meat quality response to dietary concentrations in fast-, medium- and slow-growing commercial broilers, Anim. Res. 52 (2002) 65-77.

[17] Quentin M., Bouvarel I., Picard M., Effects of the starter diet, light intensity and essential amino acids level on growth and caracass composition of broilers, J. Appl. Poultry Res. 17 (2005) 69-76.

[18] Savory C.J., Feather pecking and cannibalism, World's Poultry Sci. J. 51 (1995) 215219.

[19] Si J., Fritts C.A., Burnham D.J., Waldroup P.W., Relationship of dietary lysine level to the concentration of all essential amino acids in broiler diets, Poultry Sci. 80 (2001) 1472 1479.

[20] Sklan D., Plavnik I., Interactions between dietary crude protein and essential amino acid intake on performances of broilers, Brit. Poultry Sci. 43 (2002) 442-449.

[21] Smith E.R., Pesti G.M., Influence of broiler strain cross and dietary protein on the performance of broilers, Poultry Sci. 77 (1998) 276-281.

[22] Smith E.R., Pesti G.M., Bakalli R.I., Ware G.O., Menten J.F.M., Further studies on the influence of genotype and dietary protein on the performances of broilers, Poultry Sci. 77 (1998) 1678-1687.

[23] Surisdiarto A., Farrell D., The relationship between dietary crude protein and lysine requirement by broiler chicks on diets with and without the ìideal protein balanceî, Poultry Sci. 70 (1991) 830-836. 